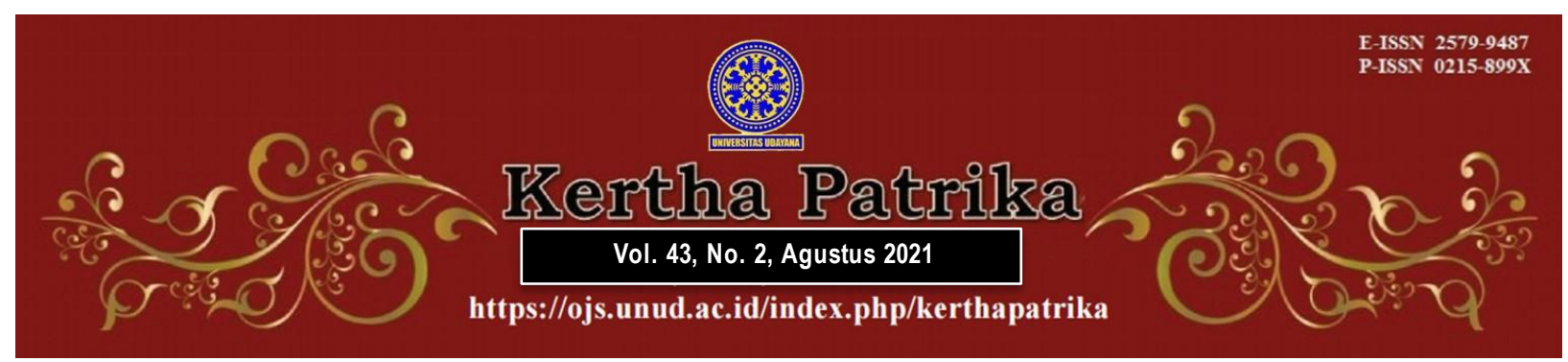

\title{
The Profit-Sharing System Between Landowners and Cultivators of Tobacco: Islamic Economic Law Perspective
}

\section{Dyah Ochtorina Susanti ${ }^{1}$}

${ }^{1}$ Faculty of Law, University of Jember, E-mail: dyahochtorina.fh@unej.ac.id

\begin{tabular}{l}
\hline Info Artikel \\
\hline Submitted : $30^{\text {th }}$ April 2021 \\
Accepted : $21^{\text {st }}$ June 2021 \\
Published : $1^{\text {st }}$ July 2021 \\
Keywords : \\
Profit-Sharing System; \\
Landowners; Cultivators of \\
Tobacco \\
Corresponding Author: \\
Dyah Ochtorina Susanti \\
E-mail: \\
dyahochtorina.fh@unej.ac.id \\
DOI : \\
10.24843/KP.2021.v43.i02.p01 \\
\hline
\end{tabular}

\begin{abstract}
This research aims to find profit-sharing system between landowners and cultivators of tobacco based on Islamic Economic Law, so that it can be used by landowners and cultivators to cooperate in cultivating tobacco fields. The method in this research using the normative legal research with the statute approach, and conceptual approach. The results of the study in the form of 3 (three) forms of profit-sharing systems between landowners and tobacco cultivators according to Islamic economic law, which can be used, namely muzara'ah, mukhabarah, and musaqah. In the final part of this research, the researcher also provides advice to landowners and cultivators to put the cooperation agreement into written form, to prevent conflicts and disputes in the future. Further suggestions are addressed to the Government. The government needs to socialize the production sharing system in agriculture according to Islamic economic law.
\end{abstract}

\section{Introduction}

Islam is a religion that regulates all aspects of human life, starting from aqidah, worship, morals, or muamalah. Islam has provided various complete rules for human life, one of which is the economics of Islamic economics. ${ }^{1}$ Islamic economic law a collection of legal norms derived from the Al-Qur'an and Hadith, regulating economic issues, or regulations regarding human economic activities. ${ }^{2}$ The provisions referred to essentially prohibit economic activities, both production, distribution, and consumption that are contrary to the norms in the Qur'an and the Prophet Hadith. ${ }^{3}$

1 Abidin, Akmal Zainal. (2015). Korelasi Antara Islam dan Ekonomi. Jurnal Penelitian, 9, (1), p. 5. doi: http://dx.doi.org/10.21043/jupe.v9i1.847.

2 Marwing, Anita. (2017). Fatwa Ekonomi Syariah di Indonesia. Al-Amwal : Journal of Islamic Economic Law, 2(2), p. 211. doi: https://doi.org/10.24256/alw.v2i2.639.

3 Turmudi, Muhammad. (2017). Produksi Dalam Perspektif Ekonomi Islam. Islamadina, XVIII (1), p. 42. doi: 10.30595/islamadina.v0i0.1528. 
The economic activities referred to above consist of various fields, starting from trade, plantation, fishery, and agriculture. In this regard, from these various economic fields, agriculture is an important aspect considering that Indonesia as an agricultural country has people who work as farmers, especially in rural areas. According to Kominfo data from the Ministry of Communication and Informatics of the Republic of Indonesia, which states that the structure of the working population according to employment in August 2019 is dominated by the agricultural sector, namely a griculture at 27.33 percent; trade amounting to 18.81 percent; and processing industry 14.96 percent. in ruralareas, the management of agricultural land owned by the owner of the land (the owner of the capital) is not managing by the landowner. ${ }^{4}$ The landowner collaboration with farmers to work on a plot of land that does not belong. This cooperation is realized through an agreement between the two parties to use a profit-sharing system. ${ }^{5}$

In connection with the definition of production sharing itself, namely agreement between the owner of the agricultural land and the cultivator, wherein the cultivator is allowed by the owner to regulate the distribution between the two parties. ${ }^{6}$ According to Seiga Khuzaema Cahyati, profit sharing is the sharing of the results of land processing (wages). That is the yield for the person who manages or cultivates the land, such as half, one-third, or more or less in accordance agreement of both parties. ${ }^{7}$

Positive Law of Indonesian, the definition of profit-sharing is regulated in Article 1 letter c of Law Number 2 of 1960 concerning Production Sharing Agreements, which contain the following:

"Production sharing agreement is an agreement with the name entered into between the owner on one party and a person or legal entity on the other party which in this law is called a cultivator, based on an agreement where the cultivator is permitted by the owner to carry out agricultural business on the owner's land with a distribution. the result is between the two parties."

Based on the explanation above, the production sharing cooperation between theowners of capital and tobacco cultivators. The owners of capital provide agriculturalland which will be managed by cultivators. the results of the work are then divided among the parties according to the agreement.

This is similar to the cooperation in the agricultural sector in Patemon Village, Krejengan Subdistrict, Probolinggo Regency, which has the potential, namely tobacco, where the landowners (tobacco landowners) collaborate with cultivators in managing the tobacco

4 https://kominfo.go.id/content/detail/22584/dominasi-sektor-pertanian-jumlah-orangbekerja-naik-250-juta/0/berita. $\backslash$ (Accessed on 3 April 2021)

5 See Wahyuningrum, Ana Liana and Darwanto. (2020). Penerapan Bagi Hasil Maro Perspektif Akad Mukhabarah. Tawazun: Journal of Sharia Economic Law, 3(1), p. 49. doi: http://dx.doi.org/10.21043/tawazun.v3i1.7544

6 Arief S. (no years). UUPA dan Hukum Agraria dan Hukum Tanah dan Beberapa Masalah Hukum Agraria dan Hukum Tanah. Surabaya : Pustaka Tirta Mas, p. 182

7 https://dspace.uii.ac.id/bitstream/handle/123456789/7081/08\%20naskah\%20publikasi. pdf? sequence $=12 \&$ is Allowed $=y$, (Accessed on 3 April 2021) 
farming land. ${ }^{8}$ In practice, the landowners only provide tobacco farming land, and cultivators provide seeds and other materials, then the business results are divided based on the percentage (profit margin) agreed upon by the parties. ${ }^{9}$ Along with the cultivation process, because the cultivation costs exceed the funds owned by cultivators, so often cultivators ask for a shortage of funds from the owner of the agricultural land, while the business results are divided according to the initial agreement without considering the costs incurred by the owner of the farm. In this regard, of course, in this case, the landowner is disadvantaged, especially the cultivators who do not report (not transparent) regarding the details of the needs needed during the cultivation process to the owner of the agricultural land. ${ }^{10}$

In connection with the above, to overcome the problems related to profit sharing between capital owners and tobacco cultivating farmers in Patemon Village, Krejengan District, Probolinggo Regency, Islamic economic law to provide a solution the profitsharing system that can be used by working parties together. Based on the above background, some things need to be studied, namely related to the cooperation between the owners of capital (agricultural land) and farmers cultivating tobacco, namely through a discussion with the central theme "The Profit-Sharing System Between Landowners and Cultivators of Tobacco (Islamic Economic Law Perspective)." The problem that becomes a legal issue in writing this scientific paper is What is the form of profit-sharing between the owners of capital and tobacco farmers according to Islamic economic law?

\section{Method Research}

This research uses a type of normative legal research (doctrinal research), which is research that aims to provide a detailed and systematic explanation that is carried out by examining various legal rules, analyzing the relationship between one legal rule and another, even can also predict the development of legal rules in the future. ${ }^{11}$ Related to this, considering that this normative legal research analyzes legal rules, the objects studied are in the form of documents of statutory regulations and library materials. 12 In this regard, the object of this research is in the form of rules or literature related to the profit-sharing system between the owner of the capital and the tenant farmers (Islamic economic law perspective).

In the implementation of this research, the authors use several approaches to examinea field of science so that research focuses on problem-solving following a predetermined scope. This approach consists of a statute legal approach and a conceptualapproach. The statute legal approach is carried out by examining laws and regulations. ${ }^{13}$ This statute

8 Susanti, Dyah Ochtorina. (2018). Laporan Pengabdian Kepada Masyarakat berjudul "Sistem Bagi Hasil Antara Pemilik Modal Dan Petani Tembakau Di Desa Patemon, Kecamatan Krejengan, Kabupaten Probolinggo (Perspektif Hukum Ekonomi Syariah). Jember: Lembaga Penelitian dan Pengabdian Kepada Masyarakat Universitas Jember, p. 2.

$9 \quad$ Ibid.

10 Ibid.

11 Susanti, Dyah Ochtorina and Efendi, A'an. (2014). Penelitian Hukum (Legal Research). (Jakarta: Sinar Grafika, p. 11.

12 Ibid.

13 Ibid., p.10. 
legal approach is used to examine statutory regulations or regulations relating to the profit-sharing system between landowners and cultivators (Islamic economic law perspective).

About the conceptual approach, it is done based on legal principles obtained in theview of legal scholars or other legal doctrines by not departing from existing regulations this approach is necessary because no rules are governing it. ${ }^{14}$ So it needs to be traced from the view point of scholars and legal doctrine as referred to a bove. The application of the conceptual approach is to trace and search for sentences that are not regulating in statutory regulations regarding the yield system between the landowners and cultivators (Islamic economic law perspective) in law books, and other legal journals.

\section{Result and Discussions}

\subsection{The mechanism for the Results of Agricultural Land Processing in the Village of Patemon, Krejenga sub-district, Probolinggo Regency.}

This research refers to a case that occurred in Patemon Village, Krejengan Subdistrict, Probolinggo Regency related to cooperation in the management of tobacco farmingland between the owners of capital and tobacco cultivators, wherein the implementation, the parties still use the existing customs or traditions in the community. The habit referred to is that tobacco landowners hand over the capital of tobacco land to cultivators to be managed, while cultivators provide seeds or seeds. 15 The distribution of the results of tobacco management in Patemon Village, Krejengan Subdistrict, Probolinggo Regency is carried out at the time of tobacco harvest, where the proceeds from the sale of tobacco are deducted from the first management costs such as irrigation costs, tobacco picking costs, etc., then the remainder is divided by 2 ( two) or 50: 50.16 It means that the distribution of the results is determined at the time of harvest, the beginning of the agreement, the parties only agree to hand over the tobacco farm to the cultivators, without discussing the distribution of the results. Moreover, both parties did not put the agreement into a written agreement, so the rights and obligations of the parties were unclear.

The lack of clarity on the rights and obligations of these parties certainly creates problems, where in the middle of tobacco land management, cultivators lack material costs or other necessities such as paying tobacco picking workers, so the tenants then ask for the shortfall from the landowner. Related to this, when the harvest arrives, theresults are divided by 2 (two) after deducting the management costs incurred by cultivators (without seeds and fertilizers), but the costs incurred by the landowner are not calculated, because the cultivator costs are also not cut from the crop. According to the landowner, fertilizers and seeds are considered as working capital for the farmers, not for the costs of managing the tobacco fields. ${ }^{17}$ Moreover, cultivators do not report (not

14 Ibid., p. 15.

15 Dyah Ochtorina Susanti, Op. Cit, p. 2.

16 Ibid., p. 3.

17 Results of an interview with Mrs. Husniyah, a tobacco ownerland in Laporan Pengabdian Kepada Masyarakat berjudul “Sistem Bagi Hasil Antara Pemilik Modal dan Petani Tembakau 
transparent) in detail regarding the needs needed during the cultivation process to the tobacco landowners, but instead directly convey the total expenditure. ${ }^{18}$ In this regard, of course, in this case, the landowner is disadvantaged, but because the production sharing agreement has become a habit, the community continues to run it.

In connection with the definition of a profit-sharing agreement itself, namely an agreement or collective agreement in carrying out business activities, in which the business is agreed to share the results of the benefits obtained between the two parties or more. ${ }^{19}$ According to Boedi Harsono in Efa Roha, et.al, a production sharing agreement is an agreement between the owner of agricultural land and a cultivator. the cultivator is allowed to cultivate the land in question, and the distribution of the results is in accordance with a mutual agreement or agreement. ${ }^{20}$ This opinion explains that the portion of the profit-sharing between the two parties is following mutual agreement. This opinion explains that the portion of the profit-sharing between the two parties is according to the agreement and the wishes of parties without being forced. ${ }^{21}$ In connection with Boedi Harsono's opinion, Hilman Hadikusumah also expressed his opinion that the production sharing agreement was a general principle in customary law. Meaning that if someone planted another person's land with consent or without consent, he was obliged to hand over part of the land's products to the landowner. This principle is not only intended for empty land, agricultural land, garden land, or rice fields, but also for aquatic land, fishery and livestock. ${ }^{22}$

\subsection{Regulation for the profit-sharing of agricultural land management in Indonesia}

In the positive law of Indonesia, the sharing agreement for agricultural land management has been regulated in Law Number 2 of 1960 concerning Production Sharing Agreements (hereinafter referred to as PBH Law). The law provides rules ranging from the subject of the agreement, the form of the agreement, the period of the agreement, to the distribution of agricultural products. Article 3 of the PBH Law states that agreement must be made in writing. The agreement must also be made by the land

di Desa Patemon, Kecamatan Krejengan, Kabupaten Probolinggo (Pers pektif Hukum Ekonomi Syariah by Dyah Ochtorina Susanti. See Ibid., p. 4.

18 Results of an interview with Mrs. Husniyah, a tobacco ownerland. Ibid., p. 4.

19 Abdullah, Muh. Ruslan. (2017). Bagi Hasil Tanah Pertanian (Muzara'ah) (Analisis Syariah dan Hukum Nasional). Al-Amwal: Journal of Islamic Economic Law 2 (2), p. 149. doi: https://doi.org/10.24256/alw.v2i2.636.

20 Roha, Efa; Silviana, Ana; and Prasetyo, Agung Basuki. (2016). Perjanjian Bagi Hasil Tanah Pertanian Pada Masyarakat Desa Bligorejo Kecamatan Doro Kabupaten Pekalongan (Perspektif Pasal 10 Uupa Menuju Terwujudnya Aspek Keadilan Masyarakat). Diponegoro Law Journal, 5 (3), p. 2.

21 Hisamuddin, Nur, and Andi A. (2015). Analisis Faktor-Faktor Yang Dipertimbangkan Dalam Penentuan Nisbah Bagi Hasil Simpanan Deposito Mudharabah Dan Perlakuan Akuntansinya Pada BPR Syariah Asri Madani Nusantara. Jurnal Bisnis dan Manajemen Islam, 3 (1), p. 143. doi: http:/ / dx.doi.org/10.21043/bisnis.v3i1.1477.

22 Abdullah, Muh. Ruslan, Op.Cit., p. 158. 
owner and the cultivating farmer in front of the Village Head, witnessed by two people and legalized by the community. ${ }^{23}$ This provision indicates that the State has obliged the community to ensure that the agricultural management production sharing agreement must be made in writing, as an effort to provide legal certainty, so that if a disputeoccurs between the two parties who entered into the agreement, evidence of written consent can be used as authentic evidence.

Furthermore, about the amount of profit-sharing in agriculture, it has been regulated in Article 7 of the PBH Law which stipulates that:

(1) The regent concerned shall determine the share of land products which are the right of the cultivator and owner for each regency, taking into account the type of plant, the condition of the land, population density, zakat set aside before distribution and economic factors as well as customary provisions. local;

(2) The regent shall notify his decision regarding the stipulation of distribution of land products taken by following paragraph 1 of this Article to the Daily Government Body and the DPRD.

The above provision implies that the amount of profit-sharing from agricultural land management is determined by the Regent in each regency by observing the matters as stated in the provision.

In this regard, the production sharing of agricultural land management as further regulated in Article 4 paragraph (1) Instruction of President the Republic of Indonesia Number 13 of 1980 concerning Guidelines for Implementing Law Number 2 of 1960 Concerning Production Sharing Agreements (hereinafter referred to Instruction President concerning PBH Implementation Guidelines), which states that agricultural land product sharing includes:

1) the type of rice grown in the paddy fields, namely 1 (one) part for the cultivator, and 1 (one) part for the landowner,

2) for secondary crops and rice planted on dry land, namely $2 / 3$ (two-thirds) for cultivators and $1 / 3$ (one-third) for landowners.

The above provision implies that the amount of profit-sharing from agricultural land management is determined by the Regent in each regency by observing the matters as stated in the provision.

In this regard, the share of land products referred to is further regulated in Article 4 paragraph (1) Instruction of President The Republic of Indonesia Number 13 of 1980 concerning Guidelines for Implementing Law Number 2 of 1960 concerning Production Sharing Agreements (hereinafter referred to as Inpres on the Implementation of PBH). which states the share of land yield for the type of rice grown in the rice fields, namely 1 (one) part for the cultivator, and 1 (one) part for the landowner, while for secondary crops and rice grown on dry land, namely $2 / 3$ (two-thirds) for cultivators and $1 / 3$ (onethird) for landowners. In this regard, it is also necessary to know that the divided results are net yields, meaning that the costs incurred during the agricultural land management process have been deducted, such as the purchase of fertilizers, seeds, planting, and

23 Rafly, Muhammad; Natsir, Muhammad; Sahara, Siti. Muzara'ah (Perjanjian Bercocok Tanam) Lahan Pertanian Menurut Kajian Hukum Islam. Jurnal Hukum Samudera Keadilan, 11(2), p. 223. 
harvesting costs, livestock, and zakat. ${ }^{24}$ In connection with the provisions, it is seen that the Inpres on the Implementation of $\mathrm{PBH}$ does not yet cover production-sharing arrangements for all types of agricultural land, considering that only 2 (two) types of plants are mentioned, namely rice and secondary crops. This means that theseprovisions do not apply to tobacco plants.

It is different from the provisions in Islamic law, where Islamic law also regulates the sharing system for the management of agricultural land, but with a broader scope. It means that the existing provisions apply to all types of plants. Its arrangement can be seen through sources of Islamic law such as Al-Qur'an, hadith, and ijtihad. Regardingthe rules in the Al-Qur'an, it is stated in the Q.S. Al-Waqi'ah Verses 63-64, translation is as follows: 25

"And have you seen that (seed) which you sow? Is it you who make it grow or are we the grower?"

There are also several Hadiths of the Prophet Muhammad which also regulate cooperation for the management of agricultural land, including the hadith narrated by Imam Muslim from Ibn Ismail and Ibn Umar, explains that:

Isma'il has told us Juwairiyah bin Asma 'from Nafi' from 'Abdullah r.a said: "Rasulullah SAW cooperated with the Jews from the land of khaibar to be used and turned into agricultural fields and they got half the results." (HR. Muslim)

Continue the Hadith History of Bukhari whose translation is as follows: ${ }^{26}$

"Who owns the land, let the land be planted, or give it to his relatives. If he does not like to give to others, then let the land remain in his possession". (HR. Bukhari).

The provisions in the Al-Quran and Hadith above show that Islamic law allowsandeven recommends that everyone who owns land or agricultural land but cannot manage, can cooperate with other people to manage the land by sharing the results.

In addition to the provisions as mentioned above, Islamic law also provides rules regarding the type of agreement, which are stated in the Hadith of the Prophet Muhammad, narrated by Bukhari and Muslim from Ibn Abbas r.a., who said that Rasulullah SAW said which means:27

"Only three kinds of people are allowed to cultivate crops: a man with land, then he is the one who has the right to plant it and a man who is giving the benefits of the land, then he is the one who cultivates it and men who rent the land with gold or silver."

24 See Article 4 paragraph (2) Instruction of President The Republic of Indonesia Number 13 of 1980 concerning Guidelines for Implementing Law Number 2 of 1960 concerning Production Sharing Agreements.

25 Departemen Agama RI. Al-Qur'an dan Terjemahannya. (Jakarta Timur: Darus Sunnah, 2002), p. 234.

26 Fielnanda, Refky and Rafidah. (2017), Produksi: Kajian Tekstual dan Kontekstual. Iltizam Journal Of Shariah Economic Research,1(1), p. 24. doi: https:/ / doi.org/10.30631/iltizam.v1i1.96.

27 Muhammad Nashiruddin Albani. (2007). Shahih Sunan An-Nasai terj. Kamaluddin Sa'diyatul Haramain. Jakarta: Pustaka Azzam, p. 51 
Referring to the hadith, in Islamic economic law, the agreement (contract) for agricultural land products is divided into 3 (three) forms, namely muzara'ah, mukhabarah, and musaqah. In this regard, even for the amount of profit-sharing, it is also regulated in one of the hadiths narrated by Bukhari from Jabir which says that the Arabs always cultivate their land muzara' $a$ h with a profit-sharing ratio of 1/3:2/3,1 / 4:3/4,1/2:1/2, the Rasulullah SAW said:28

"You have to plant or submit it for cultivation. Whoever does neither of the two, hold on to the land."

Some of the provisions above indicate that Islamic law has provided detailed and complete rules regarding the ability to carry out cooperation between landowners and cultivators, to the sharing of the results of the three types of cooperation agreements (contracts) in the processing of agricultural land, namely muzara'ah, mukhabarah, and musaqah.

\subsection{The Type of Profit-Sharing System According to Islamic Economic Law}

In connection with the agreement on the results of the first agricultural land carried out by muzara'ah. Muzara'ah has two meanings, first is Al-muzara'ah with another term alzur'ah (throwing away plants) which means capital (al-hadzar). ${ }^{29}$ Muzara'ah comesfrom the word zara'ah also means muamalah (working together) muzara'ah.30 At the level of the term, muzara'ah is a cooperation between landowners (capital owners) and cultivators, where the planted seeds come from the landowner. ${ }^{31}$ According to Syafi'i Antonio, muzara' $a h$ is cooperation in agricultural management between landownersand tenant cultivators, namely the landowner gives his agricultural land to cultivators(seeds from the landowner) to be planted and maintained in exchange for a certain share of the harvest. ${ }^{2}$ Qardhawi in Jefri Putri Nugraha argues that muzara' $a h$ is a form of muamalah where the landowner hands over tools, seeds, and animals to those who want to plant them on a condition that the landowner will get good results have been determining according to mutual consent. ${ }^{33}$ Likew ise with Fachruddin in Jefri Putri Nugraha explains the same thing, namely muzara'ah is an agreement between farmers and landowners,

28 Asaad, Mhd. (2011). Peningkatan Peranan Perbankan Syariah Untuk Pembiayaan Usaha Pertanian. MIQOT: Jurnal Ilmu-ilmu Keislaman, XXXV(1), p. 118.

29 Darmanita, and Muin. Rahmawati. (2017). Penerapan Bagi Hasil Pada Sistim Tesang (Akad Muzara'ah) Bagi Masyarakat Petani Padi di Desa Datara Kecamatan Tompobulu Kabupaten Gowa. Jurnal Iqtisaduna, 2(1), 34-54. doi: https:// doi.org/10.24252/iqtisaduna.v2i1.2395

30 Wahyu, A. Rio Makkulau. (2019). Sistem Penggarapan Lahan Pertanian Masyarakat: Perspektif Ekonomi Islam. Al-Azhar Journal of Islamic Economics, 1(1), p. 5. doi: https:// doi.org/10.37146/ajie.v1i1.9.

31 Ibid.

32 Antonio, Syafi'i. (2001). Bank Syari'ah: Teori dan Praktik. Jakarta : Gema Insana Press, p. 99

33 Jefri Putri Nugraha. (2016). Sistem Muzara'ah Sebagai Alternatif Pembiayaan Pertanian di Indonesia. IQTISHODIA: Jurnal Ekonomi Syariah, 1 (2), p. 8. doi: https://doi.org/ 10.35897 /iqtishodia.v1i2.66. 
where the landowner gives land to farmers to cultivate, and the results are dividing among the parties. ${ }^{34}$

Based on the understanding of muzara'ah above, it understood that muzara'ah is a collaboration between the owner of the capital and the cultivating farmer with a sharing of the results, where the seeds or seeds planted, as well as the materials needed during the process of managing agricultural land come from the owner of the capital, whilethe cultivator is only responsible for managing the agricultural land. In this regard, the application of muzara'ah in Patemon Village occurs when the owner of the capitalagrees to hand over tobacco land, seeds, or tobacco seeds to s cultivators to be managed, while the tenant farmers are only responsible for managing the tobacco land. For the profit sharing, according to the author, the proper distribution of the results is $1 / 3$ (one third) for the tobacco landowner and 2/3 (two thirds) for the tobacco cultivators, its yield is not deducted by the cost of seeds or other materials. The share of tobacco landowners, in this case, is greater because the seeds and the needs for managing agricultural land come from the owners of the capital themselves. In this regard, if the yield is not deducting by the cost of seeds or other materials, then the ratio that can be a user is $1 / 2$ : $1 / 2$, meaning that both tobacco landowners and tobacco cultivators get the same portion of the profit.

Concerning the form of the second agricultural land production-sharing system, namely mukhabarah, is cooperation related to agricultural processing carried out between the landowner and the tenants, in which the landowner gives a plot of land to the manager to be planted and maintained with certain rewards based on the agreement of the parties. ${ }^{35}$ Another definition of mukhabarah is a cooperation between landowners (capital) and peasants, where peasants work on land owned by landowners in exchange for a portion of the results, while the seeds come from cultivators, namely working on agricultural land whose seeds from cultivators. ${ }^{36}$ Regarding opinion of Ibrahim al-Bajuri in Muhammad Jawar, the owner only hands over the land to workers and capital from the manager. ${ }^{37}$

In connection with the explanation above, it is necessary to know that the mukhabarah contract is the opposite of the muzara'ah contract. Mukhabarah is a cooperation between the landowner and the cultivator, where the seeds and other necessities come from the cultivator. If mukhabarah is implementing in Patemon Village, then the application is that the tobacco landowner will surrender his land to the cultivating farmer to be managed, while the tobacco cultivator provides seeds or other necessities. Considering that cultivators have a bigger responsibility than landowners apart from being a land cultivator, he is also a provider of seeds and other necessities. Based on this explanation, according to the authors, the yield obtained by tobacco landowners is $1 / 3$, and for tobacco cultivating farmers it is $2 / 3$ if the dividend yield has not been deducted by the cost of seeds and others, but if the results distributed are already deducting costs seeds,

34 Ibid., p. 87.

35 Wahyu, A. Rio Makkulau. Op.Cit., p. 9.

36 Ibid., p. 2.

37 Mughniyah, Muhammad Jawwad. (2009). Fiqih Imam Ja'far Shodik. (Jakarta: Lentera, 2009), p. 110. 
fertilizers, etc., the ratio that can be using is $1 / 2$ for tobacco landowners and $1 / 2$ for a cultivator.

In connection with the third agreement, namely musaqah. At the epistemological level, musaqah comes from the word al-saqah, which is someone working on tamarind, grapes (taking care of them), or other trees that bring benefit and get a certain part of the results that are taken care of as a reward. ${ }^{38}$ according to terminology, musaqah is a contract for the maintenance of crops (agriculture) and others with certain conditions. Another definition of musaqah is a cooperation between landowners and cultivators with theaim that the land (rice fields, gardens, etc.) is maintained and cared for so that it gives maximum results, and then the results of the maintained land are joint rights between the landowner and the tenants following the agreement together. ${ }^{39}$ Musaqah is also defining as the handing over of a tree to someone to be cared for by irrigating and caring for it until the fruit is completely ripe, in exchange for a certain part of the fruit. 40

Based on the definition of musaqah above, musaqah is a collaboration between the landowner and the cultivator. The landowner over the land that is owned to the cultivator to be maintained and cared for so that it gives maximum results, and then the results are divided according to the agreement. In connection with this definition, if this form of profit-sharing system is applied to the collaboration in tobacco management in Patemon Village, Krejengan District, Probolinggo Regency, then the owner of thecapital, in this case, is obliged to hand over the tobacco land to cultivators to manage, while the tenant farmers are obliged to maintain and care for the land. tobacco so that tobacco products can be optimal. In this regard, the ratios that can be used by the parties are $1 / 3$ (one-third) and $1 / 4$ (one-quarter). This is as applied by Abubakar, Umar, Ali, and their families who use the ratio of $1 / 3$ and $1 / 4$ in profit sharing using the musaqah contract. ${ }^{4}$

In connection with the explanation as described above, it is necessary to know and understand that in implementing the three production sharing systems that can be used by the owners of capital or tobacco land and tobacco cultivators as mentioned above, the most important thing to do and often forgotten. namely the obligation to put the agreement that has been made into a written agreement, as regulated in Article 3 of the PBH Law. Matters that need to be including in the agreement include:

1. The form of the agreement used must be clearly defined (muzara'ah, mukhabarah, or musaqah);

2. An explanation regarding the object of the agreement, for example, the area of tobacco land and the location of the object;

3. The rights and obligations of the owner of capital (tobacco land) with tobacco cultivating farmers, such as the obligation of the party responsible for providing

$38 \mathrm{http}: / /$ digilib.uinsby.ac.id/920/5/Bab\%202.pdf, (Accessed on 4 April 2021).

39 Emily Nur Saidy and Ilman. (2019). Implementasi Al- Musaqah Terhadap Kesejahteraan Buruh Petik Cengkeh di Desa Kombo, Toli-Toli. LAA MAISYIR, 6 (1), p.17. doi: https:// doi.org/10.24252/lamaisyir.v6i1.9402

40 Sabiq Sayyid. (2010). Figh Sunnah. Jakarta: Pena Pundi Aksara, p. 295

41 Rivandi, Dhody Ananta and Sholihah, Cucu. (2019). Akad Pembiayaan Murabahah di Bank Syariah dalam Bentuk Akta Otentik Imolementasi Rukun, Syarat, dan Prinsip Syariah. Malang: Cita Intrans Selaras, p. 59. 
seeds, and the party who gives up the tobacco land, as well as other rights and obligations;

4. Technical expenses required during the management of tobacco land and the party responsible for it;

5. Percentage for the results of the parties involved in the tobacco land management agreement;

6. The period of validity or expiration of the production sharing agreement must also be determined;

7. Force Majeure;

8. Settlement of disputes;

9. As well as other provisions deemed necessary in the production sharing agreement between the owner of the capital and the tobacco cultivator.

In connection with the explanation above, pouring out the production sharing agreement between the owner of the capital and the farmers who cultivate tobacco, will help the parties to minimize the occurrence of disputes either that arise during the process of managing tobacco land or after the time for sharing of tobacco production has arrived. So that the parties are not arbitrary considering their rights and obligationshave been stipulated in writing in the production sharing agreement, as well as the profitsharing ratio which cannot change because it has been agreed in the agreement.

\section{Conclusion}

The profit-sharing system between the owners of capital and tobacco cultivators (according to Islamic economic law) consists of 3 forms, namely: 1) Muzara'ah is cooperation in the management of agricultural land between the landowner and the cultivator. The landowner gives agricultural land to the cultivator planted with plant seeds from the owner of the cultivated land in exchange for a reward (percentage) of the harvest. The profit-sharing ratio that can be used is $1 / 3$ (one-third) for cultivators: $2 / 3$ (two-thirds) for landowners if the business results have not been deducted by the cost of seeds and other materials. The ratio of the distribution is $1 / 2: 1 / 2$ if other costs have been deducted. 2) Mukhabarah is a cooperation between landowners and tenants with the agreement that the results will be divided by the ratio between landowners and cultivators according to mutual agreement. The costs and the seeds from the land cultivator. The profit-sharing ratio that can be used is $1 / 3$ (one-third) for landowners and $2 / 3$ (two-thirds) for cultivators if the results include the cost of seeds and other materials. If it does not include the usual seeds and other materials, the ratio is $1 / 2: 1 / 2.3$ ) Musaqah, namely a cooperation agreement between the landowner and the cultivator where the cultivator is only responsible for watering and maintenance as a reward, the cultivator is entitled to a certain ratio of the harvest. The profit-sharing ratios that can be used are $1 / 3$ and $1 / 4$. It must be understood, the profit-sharing ratio above must be following the agreement of the parties. Furthermore, the agreement is contained in a written agreement so that there are no conflicts related to the cooperation in the management of tobacco land between the owners of the capital and the tobacco cultivators. In this research, the author also gives advice (suggestion) to the community and Government. To the community, especially landowners and cultivators, to put the agricultural land management cooperation agreement into written form, in order to prevent conflicts or disputes in the future. To the Government. The government needs to socialize the production sharing system in the agricultural sector according to shari'ah 
economic law to the community, especially farmers so that in the production sharing agreement no one is harmed.

\section{References}

\section{$\underline{\text { Books }}$}

Albani, Muhammad Nashiruddin. (2007) Shahih Sunan An-Nasai terj. Kamaluddin Sa'diyatul Haramain. Jakarta: Pustaka Azzam.

Antonio, Syafi'i. (2001). Bank Syari'ah: Teori dan Praktik. Jakarta : Gema Insana Press.

Arief S. (no years). UUPA dan Hukum Agraria dan Hukum Tanah dan Beberapa Masalah Hukum Agraria dan Hukum Tanah. Surabaya : Pustaka Tirta Mas.

As-Shiddieqy, Teungku Muhammad Hasbi. (1997). Hukum-Hukum Fikih Islam. Semarang: Pustaka Rizki Putra.

Departemen Agama RI. (2002). Al-Qur'an dan Terjemahannya. Jakarta Timur: Darus Sunnah.

Mughniyah, Muhammad Jawwad. (2009). Fiqih Imam Ja'far Shodik. Jakarta: Lentera.

Rivandi, Dhody Ananta and Sholihah, Cucu. (2019). Akad Pembiayaan Murabahah diBank Syariah dalam Bentuk Akta Otentik Imolementasi Rukun, Syarat, dan Prinsip Syariah. Malang: Cita Intrans Selaras.

Sabiq, Sayyid. (2010). Figh Sunnah. Jakarta: Pena Pundi Aksara.

Susanti, Dyah Ochtorina (2018). Laporan Pengabdian Kepada Masyarakat berjudul "Sistem Bagi Hasil Antara Pemilik Modal Dan Petani Tembakau Di Desa Patemon, Kecamatan Krejengan, Kabupaten Probolinggo (Perspektif Hukum Ekonomi Syariah). Jember: Lembaga Penelitian dan Pengabdian Kepada Masyarakat Universitas Jember.

Susanti, Dyah Ochtorina and Efendi, A'an. (2014) Penelitian Hukum (Legal Research). Jakarta: Sinar Grafika.

\section{Journal}

Abdullah, Muh. Ruslan. (2017). Bagi Hasil Tanah Pertanian (Muzara'ah) (Analisis Syariah dan Hukum Nasional). Al-Amwal: Journal of Islamic Economic Law 2 (2), doi: https://doi.org/10.24256/alw.v2i2.636

Abidin, Akmal Zainal. (2015). Korelasi Antara Islam dan Ekonomi. Jurnal Penelitian 9, (1), doi: http://dx.doi.org/10.21043/jupe.v9i1.847.

Asaad, Mhd. (2011). Peningkatan Peranan Perbankan Syariah UntukPembiayaanUsaha Pertanian. MIQOT: Jurnal Ilmu-ilmu Keislaman, XXXV(1).

Darmanita, and Muin. Rahmawati. (2017). Penerapan Bagi Hasil Pada Sistim Tesang (Akad Muzara'ah) Bagi Masyarakat Petani Padi di Desa Datara Kecamatan Tompobulu Kabupaten Gowa. Iurnal Iatisaduna, 2(1), 34-54. doi: https://doi.org/10.24252/iqtisaduna.v2i1.2395.

Emily Nur Saidy and Ilman. (2019). Implementasi Al- Musaqah Terhadap Kesejahteraan Buruh Petik Cengkeh di Desa Kombo, Toli-Toli. LAA MAISYIR, 6 (1), doi: https://doi.org/10.24252/lamaisyir.v6i1.9402

Fielnanda, Refky and Rafidah. (2017), Produksi: Kajian Tekstual dan Kontekstual. Ittizam Journal Of Shariah Economic Research, 1(1), p. 24 . doi: https://doi.org/10.30631/iltizam.v1i1.96. 
Hisamuddin, Nur, and Andi A. (2015). Analisis Faktor-Faktor Yang Dipertimbangkan Dalam Penentuan Nisbah Bagi Hasil Simpanan Deposito Mudharabah Dan Perlakuan Akuntansinya Pada BPR Syariah Asri Madani Nusantara. Jurnal Bisnis dan Manajemen Islam, 3 (1), p. 143. doi: http://dx.doi.org/10.21043/ bisnis.v3i1.1477.

Marwing, Anita. (2017). Fatwa Ekonomi Syariah di Indonesia. Al-Amwal : Journal of Islamic Economic Law, 2(2), doi: https://doi.org/10.24256/alw.v2i2.639.

Nugraha, Jefri Putri. (2016). Sistem Muzara'ah Sebagai Alternatif Pembiayaan Pertanian di Indonesia. Jurnal Ekonomi Syariah IQTISHODIA, 1(2), doi: https://doi.org/10.35897/iqtishodia.v1i2.66.

Rafly, Muhammad; Natsir, Muhammad; Sahara, Siti. Muzara'ah (Perjanjian Bercocok Tanam) Lahan Pertanian Menurut Kajian Hukum Islam. Jurnal Hukum Samudera Keadilan, 11(2), 223. .

Roha, Efa; Silviana, Ana; and Prasetyo, Agung Basuki. (2016). Perjanjian Bagi Hasil Tanah Pertanian Pada Masyarakat Desa Bligorejo Kecamatan Doro Kabupaten Pekalongan (Perspektif Pasal 10 Uupa Menuju Terwujudnya Aspek Keadilan Masyarakat). Diponegoro Law Journal, 5 (3), 2.

Turmudi, Muhammad. (2017). Produksi Dalam Perspektif Ekonomi Islam. Islamadina, XVIII (1), doi: 10.30595/islamadina.v0i0.1528.

Wahyu, A. Rio Makkulau. (2019). Sistem Penggarapan Lahan Pertanian Masyarakat: Perspektif Ekonomi Islam. Al-Azhar Journal of Islamic Economics, 1(1), p. 5. doi: https://doi.org/10.37146/ajie.v1i1.9.

Wahyuningrum, Ana Liana and Darwanto. (2020). Penerapan Bagi Hasil Maro Perspektif Akad Mukhabarah. Tawazun: Journal of Sharia Economic Law, 3(1). doi: http://dx.doi.org/10.21043/tawazun.v3i1.7544/

\section{Online/World Wide Web}

https://dspace.uii.ac.id/bitstream/handle/123456789/7081/08\%20naskah\%20publika si.pdf? sequence $=12 \&$ isAllowed $=y$. (Accessed on 3 April 2021)

https://kominfo.go.id/content/detail/22584/dominasi-sektor-pertanian-jumlahorang-bekerja-naik-250-juta/0/berita., (Accessed on 3 April 2021)

http://digilib.uinsby.ac.id/920/5/Bab\%202.pdf, (Accessed on 4 April 2021)

\section{$\underline{\text { Regulations }}$}

Law Number 2 of 1960 Concerning Production Sharing Agreements.

Instruction of President The Republic of Indonesia Number 13 of 1980 concerning Guidelines for Implementing Law Number 2 of 1960 concerning Production Sharing Agreements. 